Marquette University

e-Publications@Marquette

Nursing Faculty Research and Publications

Nursing, College of

9-1-2014

\title{
Are Rural and Urban Newly Licensed Nurses Different? A Longitudinal Study of a Nurse Residency Programme
}

Marilyn Meyer Bratt

Marquette University, marilyn.bratt@marquette.edu

Marianne Baernholdt

Virginia Commonwealth University

Jessica E. Pruszynski

Medical College of Wisconsin

Accepted version. Journal of Nursing Management, Vol. 22, No. 6 (September 2014): 779-791. DOI.C 2012 John Wiley \& Sons Ltd. Used with permission. 


\title{
Are Rural and Urban Newly Licensed Nurses Different? Results from a Nurse Residency Program
}

\author{
Marilyn Meyer Bratt \\ College of Nursing, Marquette University \\ Milwaukee, WI \\ Marianne Baernholdt \\ School of Nursing, University of Virginia \\ Charlottesville, VA \\ Jessica Pruszynski \\ Medical College of Wisconsin Division of Biostatistics \\ Milwaukee, WI
}

\section{Introduction}

Recruitment and retention of newly licensed nurses are critical to sustaining the nursing workforce. New nurses are particularly needed to offset the nursing shortage that is anticipated due to the fallout of the current recession, the need to replace the aging nurse workforce, and the escalation of health needs of our general aging population (Buerhaus et al. 2009). For the newly licensed nurse poor work environments, incivility, and high stress levels impede nurses' role transition and assumption of professional identity (Duchscher \& Myrick 2008, Pellico et al. 2009). Since these factors contribute to nurse turnover they will further exacerbate the looming shortage. Particularly in rural settings, the supply and demand of nurses is more 
significantly imbalanced due to the increasing proportion of rural elders needing care and a growing trend of younger rural residents' migration to urban areas (Baernholdt 2012, Bushy 2002, IOM 2005, Krebs 2008).

Nurse managers need to be cognizant of the best strategies to recruit and retain new graduate nurses. One such strategy is a nurse residency program, which is directed at helping newly graduated nurses bridge the education to practice gap. A number of nurse residency programs, primarily situated in urban acute care settings, have been described in the literature (Beyea et al. 2007, Bratt 2009, Krugman et al. 2006, Rosenfeld et al. 2004, Ulrich et al. 2010). Nurse residency programs have been shown to not only reduce turnover, but also enhance quality of care and patient safety (Beecroft et al. 2001, Krugman, et al. 2006, Romyn et al. 2009). There are but a few existing nurse residency programs for rural nurses in the United States (Boyer 2002, Bratt 2009, Keahey 2008, MacLeod et al. 2008, Molinari et al. 2008) and evidence is sparse regarding the outcomes of these rural programs. Therefore, the aim of the present study is to explore whether rural and urban nurse residency programs produce different outcomes and if rural and urban new nurses have similar perceptions of their transition experience.

This study is part of a series of investigations involving newly licensed nurses who were participants in the Wisconsin Nurse Residency Program offered at rural and urban sites throughout the state (Bratt 2009, Bratt \& Felzer 2011). Consisting of monthly all-day educational sessions and mentoring, the residency program began approximately three months after hire following the initial orientation and competency validation phase that is typically guided by a preceptor. The underlying goals of the residency program were to foster professional role transition and skill development and to promote factors that contribute to retention, such as job satisfaction. The specific program outcomes were to increase nurse residents' decision-making ability, job satisfaction, nursing role performance, organizational commitment, and to decrease job stress.

Characteristics and perceptions regarding the orientation experience, work environment, and skill development of residency

Journal of Nursing Management, Vol. 22, No. 6 (September 2014): pg. 779-791. DOI. This article is (C Wiley and permission has been granted for this version to appear in e-Publications@Marquette. Wiley does not grant permission for this article to be further copied/distributed or hosted elsewhere without the express permission from Wiley. 
program participants who were newly licensed nurses employed in rural hospitals (rural nurse residents) and those employed in urban hospitals (urban nurse residents) were compared. Specific research questions were: 1.) Do personal characteristics, post-hire job characteristics and nurse residents' perceptions of orientation differ between rural and urban nurse residents? 2.) Do rural and urban nurses' perceptions differ across time in relationship to the program outcomes of decision-making ability, job satisfaction, job stress, nursing performance, and organizational commitment? 3.) Does hospital setting (rural vs. urban) moderate the relationship between time and nurse residents' perceptions of decision-making ability, job satisfaction, job stress, nursing performance, and organizational commitment?

\section{Literature Review}

\section{New Graduate Nurse Turnover}

Turnover in the new graduate population is a documented phenomenon with reports indicating that during the first year of practice new Registered Nurse (RN) turnover rates range from $18 \%$ to $50 \%$ (Brewer et al. 2009, Salt et al. 2008). In rural settings new nurse turnover has been reported to be as high as $60 \%$. The primary reasons for this staggering turnover rate were attributed to nurses' lack of competency to handle conflict, make critical decisions, and function autonomously (Keahey 2008).

New graduate turnover is expensive for organizations since it can approximate a nurses' annual salary (Beecroft et al. 2001, Bratt 2009, Keller et al. 2006). Given that rural healthcare organizations can have up to a $22 \%$ salary differential deficit compared to urban organizations, turnover can have a more profound effect in rural hospitals. Furthermore, compared to urban settings, recruitment and retention of staff is more challenging in rural hospitals because there is a smaller population of nurses to draw from and salaries are lower (LaSala 2000, Skillman et al. 2007). A lack of access to higher education and continuing education programs as well as decreased professional development support create additional barriers to

Journal of Nursing Management, Vol. 22, No. 6 (September 2014): pg. 779-791. DOI. This article is (C) Wiley and permission has been granted for this version to appear in e-Publications@Marquette. Wiley does not grant permission for this article to be further copied/distributed or hosted elsewhere without the express permission from Wiley. 
NOT THE PUBLISHED VERSION; this is the author's final, peer-reviewed manuscript. The published version may be accessed by following the link in the citation at the bottom of the page.

cultivating and retaining a quality nurse workforce in rural practice settings (McCoy 2009, Murray et al. 2011).

\section{Transition to Practice}

Ineffective transition to practice and a stressful work environment are key factors causing job dissatisfaction and turnover in nurses beginning their new career (Beecroft et al. 2008, Bowles \& Candela 2005, Casey et al. 2004). New graduates entering practice experience cognitive dissonance between personal expectations and the realities of practice with an increased expectation for rapid role assimilation to "hit the ground running". These new graduates express a persistent underlying fear of making mistakes (Bowles \& Candela 2005, Pelico et al. 2009, Romyn et al. 2009, Spector \& Li 2007). Also troublesome for new nurses is their underdeveloped skill to handle issues in the work environment including horizontal violence, negative cultures, and interactions with physicians (Duchscher \& Myrick 2008, Dyess \& Sherman 2009, Griffin 2004, McKenna et al. 2003). All of these factors cause job stress, which in turn influences job satisfaction and organizational commitment, and subsequent decision to leave a job (Beecroft et al. 2008, Bowles \& Candela 2005, Casey et al. 2004, Coomber \& Barriball 2007). Of significant concern is that stress not only impacts retention; it is also associated with increased risk for breaches in patient safety (Elfering et al. 2006, NCSBN 2009).

Challenges that are specific to new nurses in rural areas include the need to take on extended practice roles, engage in more independent decision-making, and early assumption of leadership and management roles due to fewer nurses and absence of other health professionals (Hegney \& McCarthy 2000, Kenny \& Duckett 2003). Furthermore, lack of support from preceptors and mentors, nonexistence of a formal orientation or nurse residency program, and insufficient educational resources have also been identified as contributors to stress and turnover for new rural nurses (Keahey 2008, Lea \& Cruickshank 2005, Squires 2002). For new urban nurses, job stress levels have been shown to peak between three to nine months after hire suggesting that retention interventions are especially crucial at that time (Beecroft et al. 2008, Fink et al. 2008). Whether this pattern is similar for new nurses in rural settings is unclear.

Journal of Nursing Management, Vol. 22, No. 6 (September 2014): pg. 779-791. DOI. This article is (C Wiley and permission has been granted for this version to appear in e-Publications@Marquette. Wiley does not grant permission for this article to be further copied/distributed or hosted elsewhere without the express permission from Wiley. 
NOT THE PUBLISHED VERSION; this is the author's final, peer-reviewed manuscript. The published version may be accessed by following the link in the citation at the bottom of the page.

\section{Nurse Residency Programs}

The quality of new graduates' transition experience affects retention rates (Williams et al. 2007) and perception of an insufficient orientation period escalates the difficulties that new nurses encounter (McCoy 2009, Squires 2002). When new graduates feel that they have had an adequate orientation they are more likely to perceive that they are able to accomplish their work tasks and have control over independent decision-making (Unruh \& Nooney 2011). Nurse residency programs provide support during the transition period and address new nurses' lack of practice readiness. Aimed at easing the difficult role transition and diminishing the influence of stressful work demands, residency programs decrease stress, bolster confidence, and increase job satisfaction and job performance of newly licensed nurses (Anderson et al. 2009, Goode et al. 2009, Beyea 2007). Residency programs also support professional socialization, namely transition to competent care-giver, integration into the professional nursing role, and assumption of professional identity (Kramer et al. 2011). Organizations that have residency programs have noted cost savings due to diminished turnover and decreased nurse vacancy (Halfer et al. 2008, Pine \& Tart 2007).

\section{Rural Nursing Practice}

A number of authors have advocated that compared to nursing in urban areas, rural nursing is itself a specialty, associated with unique competencies that require particular skill in providing emergent care across the age continuum (Bushy 2000, Hurme 2009, Lee \& Winters 2006). Hence, the scope of practice for rural nurses tends to be generalized rather than focused on one specialty area. Additionally, rural nurses need to initiate therapies that are typically provided by other members of the health care team in urban settings and are expected to work with a higher degree of independence with limited or delayed access to resources (Hegney et al. 2002, McCoy 2009, Scharff 2010).

Further distinguishing features of rural nursing practice include the high degree of community visibility that rural nurses perceive and a unique interconnectedness between nurses' professional and

Journal of Nursing Management, Vol. 22, No. 6 (September 2014): pg. 779-791. DOI. This article is (C) Wiley and permission has been granted for this version to appear in e-Publications@Marquette. Wiley does not grant permission for this article to be further copied/distributed or hosted elsewhere without the express permission from Wiley. 
personal lives leading to blurring of nurses' community and professional roles (Baernholdt et al. 2010, Bushy 2000). Zibrik and colleagues (2010) describe this as "permeability between the rural workplace and the community setting" and suggest that rural nurses' sense of professionalism is inextricably linked to their workplace and their community. In fact experienced rural nurses utilize their knowledge of their patients outside of the hospital to better plan their health care within the hospital (Baernholdt et al. 2010).

Rural healthcare settings have limited monetary resources and inadequate professional support (Baernholdt et al. 2010, Jukkala et al. 2008). Therefore, continuing nursing role development in rural settings can be more challenging than in urban settings. Unlike nurses practicing in larger healthcare facilities, nurses in rural settings experience geographically-induced isolation as well as professional isolation. This professional isolation has been cited as a practice barrier for rural nurses (Winters \& Mayer 2002, Beatty 2001). Additionally, fewer numbers of advanced practice nurses in rural settings can lead to fewer skilled mentors to guide the professional role integration of new graduate nurses. These dissimilarities in scope of practice, the relationship that rural nurses have with their community, and financial constraints of rural hospitals suggest a need to explore whether the same nurse residency program produces different results in rural and urban areas.

\section{Methodology}

\section{Design and Sample}

A longitudinal cohort design, collecting data three times, was employed. Newly licensed registered nurses working in acute care hospitals from 2005-2008 participated in the study (Bratt 2009, Bratt \& Felzer 2011). The total sample consisted of 468 nurse residents, 86 from 15 rural hospitals and 382 from ten metropolitan hospitals. The rural hospitals were located in nonmetropolitan areas and had 15 100 beds. The urban residents worked in hospitals that had $237-949$ beds. Rural and urban residents cared for predominantly medicalsurgical patients and worked comparable shift-types and hours.

Journal of Nursing Management, Vol. 22, No. 6 (September 2014): pg. 779-791. DOI. This article is @ Wiley and permission has been granted for this version to appear in e-Publications@Marquette. Wiley does not grant permission for this article to be further copied/distributed or hosted elsewhere without the express permission from Wiley. 
NOT THE PUBLISHED VERSION; this is the author's final, peer-reviewed manuscript. The published version may be accessed by following the link in the citation at the bottom of the page.

\section{Data Collection}

The study was approved by the Institutional Review Board of the primary investigator's university and by individual participating hospitals. After consents were obtained, data were collected from nurse residency program cohorts during the regularly scheduled educational sessions. Baseline data were collected at the beginning of the residency program (T1), again at six months at the residency program midpoint (T2), and finally at twelve months when the program concluded (T3). All nurse residents in the program were invited to be involved in the study with $61 \%$ deciding to participate ( $84 \%$ of rural residents and $58 \%$ of urban residents).

\section{Variables and Measures}

\section{Personal Characteristics, Post-Hire Job Characteristics, and Orientation}

These variables were collected via a demographic questionnaire. Along with basic demographic data, additional items focused on prelicensure education such as type of nursing degree, whether prior to graduation they had participated in role socialization coursework, and the number of hours they had worked with a nurse preceptor as a student. Questions about the post-hire orientation experience prior to entering the nurse residency program were also included. These items referred to aspects associated with bringing new nurses into the organization and the educational support to guide new nurses' successful transition to competent practitioners. This included hours of classroom orientation, number of weeks precepted, number of preceptors, and whether orientation objectives were met.

\section{Dependent Variables: Program Outcomes}

Outcome variables included decision-making ability, job satisfaction, job stress, nursing performance, and organizational commitment. Decision-making ability was defined as the conscious, cognitive process of being able to make decisions in clinical practice. It was operationalized by Jenkin's (1985) Clinical Decision Making in Nursing Scale that consisted of 40 items on a five-point Likert scale.

Journal of Nursing Management, Vol. 22, No. 6 (September 2014): pg. 779-791. DOI. This article is (C) Wiley and permission has been granted for this version to appear in e-Publications@Marquette. Wiley does not grant permission for this article to be further copied/distributed or hosted elsewhere without the express permission from Wiley. 
Job satisfaction was defined as being content with and generally liking one's job. Measured by the Nurse Job Satisfaction Scale (Hinshaw \& Atwood 1985), this instrument contains 23 items each scored on a five-point Likert Scale and includes three subscales: enjoyment, quality of care, and time to provide care. Higher scores on these scales indicate greater decision-making ability and job satisfaction, respectively.

Job stress was viewed as stress related to the work environment and being able to perform one's job. Measured by the Job Stress Scale (Hinshaw \& Atwood 1985), the scale contains 22 items on a four-point Likert scale, with higher mean scores indicating greater stress. Four subscales comprise the instrument including: competence, physical work environment, staffing, and team respect.

Nursing performance, described as the ability to perform nursing job functions, was measured by the Modified 6- $D$ Scale of Nursing Performance. The scale was originally developed by Schwirian (1978) and later revised by Marshalleck (1997). The instrument includes 61 items organized around seven areas of basic nursing competency including managing acute emergent health problems, interpersonal relations/communications, leadership skills, planning/evaluation, professional development, teaching/collaboration, and behaviors that contribute to achieving positive care outcomes and unit goals. Finally, organizational commitment, defined as the dedication or loyalty to an organization, was measured with Mowday, Steers and Porter's Organizational Commitment Questionnaire (1979). Consisting of 15 items on a seven-point Likert scale, this instrument is a valid indicator of turnover intent (Wagner 2007). Higher scores on both instruments indicate more positive ratings of nursing performance and organizational commitment.

\section{Data Analysis}

Descriptive and inferential statistical methods were employed to analyze the data using SPSS 19.0 and SAS 9.2. A repeated measures ANOVA was conducted to assess the influence of hospital setting (rural vs. urban) on participants' scores on decision-making, job satisfaction, job stress, organizational commitment, and nursing performance

Journal of Nursing Management, Vol. 22, No. 6 (September 2014): pg. 779-791. DOI. This article is (C) Wiley and permission has been granted for this version to appear in e-Publications@Marquette. Wiley does not grant permission for this article to be further copied/distributed or hosted elsewhere without the express permission from Wiley. 
across the three time periods: T1, T2 and T3. For significant main or interaction effects Tukey's Least Significant Difference (LSD) post hoc test was used to determine at which time period the specific differences between rural and urban residents occurred. To determine significant differences in personal characteristics, post-hire characteristics, and perception of orientation, t-tests and chi square analyses were performed.

\section{Results}

\section{Personal Characteristics, Post-Hire Characteristics and Perceptions of Orientation}

As Table 1 indicates, rural residents were significantly older than urban, all were Caucasian and a larger proportion had associate degrees versus baccalaureate degrees. Rural nurse residents spent less hours working with a preceptor as a student. However, there were no significant differences in participation in professional role transition coursework prior to receiving their nursing degree.

For the initial orientation experience following post-hire, rural nurse residents worked with significantly fewer nurse preceptors $(M=3.8, S D=2.3)$ compared to urban nurse residents $(M=4.9, S D=$ 3.1) No differences were found related to other elements of orientation including number of hours the nurse residents spent in classroom education, weeks spent working with a preceptor, or whether residents felt that their orientation goals were met.

\section{Within Group Differences in Rural and Urban Residents over Time}

There were significant changes in all the program outcomes over time for rural and urban residents (Table 2). For the urban sample, there were significant increases from T2 to T3 on the mean scores of decision-making and job satisfaction. Compared to program start, organizational commitment was significantly lower at T2 and T3.

Journal of Nursing Management, Vol. 22, No. 6 (September 2014): pg. 779-791. DOI. This article is (C) Wiley and permission has been granted for this version to appear in e-Publications@Marquette. Wiley does not grant permission for this article to be further copied/distributed or hosted elsewhere without the express permission from Wiley. 
Rural and urban residents demonstrated similar trends in job stress and nursing performance scores. For both populations, job stress scores at program end (T3) were found to be significantly lower than at baseline (T1) and at program midpoint (T2). Mean scores of nursing performance showed significant incremental increases between each of the three time periods.

In further analysis of the job satisfaction subscales, quality of care and time for care, urban residents had significantly higher scores at T3 compared to both T1 and T2 while rural residents had significantly higher scores at T3 compared to only T1. Urban residents also had significantly lower mean scores on the job satisfaction enjoyment subscale at T2 compared to T3, while rural nurses had no significant changes over time. The job stress staffing subscale scores showed significantly different patterns of change between rural and urban residents. Rural residents had significantly lower mean scores at T3 compared to T2 while urban residents had higher mean scores at T2 compared to T1.

\section{Differences between Rural and Urban Nurse Residents}

Job stress and job satisfaction were found to be significantly different between rural and urban nurse residents at specified time periods as illustrated in Table 2 and depicted in Figures 1 and 2. Post hoc analysis revealed that rural residents had significantly higher job satisfaction scores at residency program end (T3) as compared to urban residents. Rural residents had significantly lower job stress scores at program end compared to urban residents. Rural residents scored significantly lower at all three time periods on the job stress physical environment subscale compared to urban residents (Figure 3) and also scored significantly lower in the job stress staffing subscale at program end (T3).

There were no significant interactions between hospital setting (rural vs. urban) and time for any of the dependent variables total scale scores. However, there was a significant interaction effect between hospital setting and time for the staffing subscale of the Job Stress Scale $F(2,571)=4.06, p=.02$ (Figure 4). Rural residents perceived significantly less stress relative to adequacy of staffing at

Journal of Nursing Management, Vol. 22, No. 6 (September 2014): pg. 779-791. DOI. This article is (C) Wiley and permission has been granted for this version to appear in e-Publications@Marquette. Wiley does not grant permission for this article to be further copied/distributed or hosted elsewhere without the express permission from Wiley. 
program end (T3) compared to program midpoint (T2), whereas urban residents demonstrated no differences between T3 and either T1 or T2 and had significantly higher stress at program midpoint (T2) compared to the program start (T1).

\section{Discussion}

\section{Personal Characteristics and Initial Orientation Experience}

During their primary nursing education program, rural and urban nurse residents had similar exposure to coursework that prepared them for professional role socialization; however, urban residents had greater opportunities to work with preceptors. Rural nurse residents reported working with fewer preceptors during their initial post-hire orientation period than their urban colleagues. This finding is not surprising since rural hospitals have smaller numbers of staff nurses and therefore a smaller preceptor pool. Since increased number of preceptors has been associated with increased stress levels (Squires 2002), rural residents' exposure to fewer preceptors may provide for consistency that not only decreases stress but also accelerates achievement of the orientation goals.

\section{Job Satisfaction and Job Stress}

Rural residents experienced higher levels of job satisfaction and lower levels of stress compared to urban residents. Other studies have mixed findings when comparing rural and urban nurses' job satisfaction (Albion et al. 2005, Baernholdt \& Mark 2009, Ingersoll et al. 2002, Ndiwane 2003). In our study, urban residents reported higher job stress levels related to the work environment and staffing when compared to rural residents. This confirms previous findings where urban nurses experienced higher job stress in relationship to the physical work environment and staffing (Albion et al. 2005). However, several plausible explanations may explain the differences in both satisfaction and stress found in this study. First, the unique context of nursing care delivery and characteristics of nursing practice in rural and urban hospital settings may account for the differences in

Journal of Nursing Management, Vol. 22, No. 6 (September 2014): pg. 779-791. DOI. This article is (C) Wiley and permission has been granted for this version to appear in e-Publications@Marquette. Wiley does not grant permission for this article to be further copied/distributed or hosted elsewhere without the express permission from Wiley. 
nurses' job satisfaction and job stress found in the study. In urban settings the faster work pace and higher patient acuity may be perceived as more stressful by the nurses. On the other hand, urban nurses do have more resources readily available than in rural settings. However, the lower levels of stress found in rural nurses may be attributed to higher levels of autonomy since they are required to function more independently. More autonomy has been associated with higher positive perceptions of the work environment and enhanced job effectiveness, both of which contribute to less stress (Krebs et al. 2008, Lee \& Winters 2006, Laschinger et al. 2003). Finally, job satisfaction and intent to stay have been associated with other features of rural nursing practice, such as cohesiveness and strong teamwork (Hegney et al. 2002, Zibrik et al. 2010). Nurse residency programs can help the new graduate nurse adjust to these unique features of the work environment in rural and urban hospital settings.

Secondly, Karasek's (1998) model of Job Demand and Job Decision may further explain the differences in job satisfaction and job stress between rural and urban residents. In this model, high job demands coupled with decreased autonomy (job decision) to deal with stressors and control work activity result in mental job strain and contribute to job dissatisfaction. Social support can diminish job demands and subsequently increase job satisfaction (Hausser et al. 2010) whereas lack of social support and work overload contribute to emotional exhaustion or burnout and turnover (Janssen et al. 1999). A nurse residency program is a way to provide critical social support and collegial network throughout the first year of practice.

Third, applying the construct of job embeddedness, advanced by Mitchell (2001) may offer insight as to the variances in job satisfaction between the rural and urban nurses. Comprised of three elements perception of links to other people, fit with the organization and community, and sacrifice associated with leaving the job - job embeddedness has been related to job satisfaction, organizational commitment, and turnover. Due to the smaller number of staff members in rural hospitals and nurses' respected role in the community, rural nurses may perceive increased associations or links with their work group and their community, which more notably

Journal of Nursing Management, Vol. 22, No. 6 (September 2014): pg. 779-791. DOI. This article is @ Wiley and permission has been granted for this version to appear in e-Publications@Marquette. Wiley does not grant permission for this article to be further copied/distributed or hosted elsewhere without the express permission from Wiley. 
influences their job satisfaction. Nurses practicing in urban settings typically do not have this community connection. For rural nurses, community involvement is a source of pride and it has been strongly associated with rural nurses' values and perception of their professional role (Zibrik et al. 2010). Nurse residency programs tailored to rural settings can help new nurses realize the advantages of the higher levels of job embeddedness in rural areas.

Lastly, it is plausible that the residency program filled a more critical professional development void for rural residents compared to urban residents. Contrary to urban settings, nurses in rural healthcare organizations typically have more limited professional development opportunities and fewer resources to guide their transition to practice. Based on this, the rural residents may have viewed the residency program as the primary educational vehicle to help them learn and grow as professionals. Involvement in the program also may have made the rural residents feel privileged and valued by their organization, thereby increasing their satisfaction. Urban settings tend to have more continuing education options to meet staff learning needs. Hence, urban residents most likely had greater access to professional development activities and may have perceived fewer unique program benefits, which could have led to less engagement in the learning process. The $84 \%$ response rate of rural residents participating in this study compared to only $58 \%$ of urban residents supports this notion of the different engagement between the groups. Finally, the residency program also provided the crucial element of peer social support that rural new graduates typically lack, which may have more significantly influenced their satisfaction and promoted stress resiliency.

\section{Organizational Commitment}

Rural residents' organizational commitment did not significantly change during the residency program, whereas urban nurses' organizational commitment was significantly higher at program start than at program midpoint and program end. Since job satisfaction is a significant predictor of organizational commitment (Bratt \& Felzer in press), for rural residents, their sustained job satisfaction during the residency program may be serving to maintain their commitment to

Journal of Nursing Management, Vol. 22, No. 6 (September 2014): pg. 779-791. DOI. This article is (C) Wiley and permission has been granted for this version to appear in e-Publications@Marquette. Wiley does not grant permission for this article to be further copied/distributed or hosted elsewhere without the express permission from Wiley. 
the organization. The stability of organizational commitment throughout the program for rural residents may reflect the lack of other job choices, leading to an increased dedication to their employing hospital or a commitment to their community and hospital, as described in previous studies (Baernholdt et al. 2010, Baernholdt et al. 2011).

\section{Competency Development: Nursing Performance and Decision-Making}

Increasing professional competency is an expected outcome during the first year of practice for new nurses. In this study, rural and urban residents demonstrated almost identical paths in their ascent of the steep learning curve to become competent health care practitioners. The two groups did not significantly differ in perceptions of their ability to perform activities associated with their nursing role. These findings support the notion that regardless of setting, new graduate nurses undergo significant knowledge explosion and rapid skill acquisition.

It is interesting to note that decision-making at program end was not significantly different than the baseline measure for either group. However, at program midpoint (T2) urban residents reported significantly lower decision-making scores than at program endpoint (T3). Diminished decision-making scores at program midpoint may reflect a "crisis in confidence." This crisis includes feelings of inadequacy in clinical knowledge and ability to make decisions that new graduates can experience during the process of becoming a professional (Bratt \& Felzer 2011, Duchscher 2008). The lack of increase in decision-making in the nurse residents may be because it has been found that this critical skill takes longer than a year to develop (Benner et al. 2009).

\section{Study Strengths and Limitations}

To our knowledge, this is the first study to compare rural and urban nurse residency program outcomes. Our results can be used to create a residency program that is best matched to either setting. Our findings also add to the body of knowledge about new nurses'

Journal of Nursing Management, Vol. 22, No. 6 (September 2014): pg. 779-791. DOI. This article is (C) Wiley and permission has been granted for this version to appear in e-Publications@Marquette. Wiley does not grant permission for this article to be further copied/distributed or hosted elsewhere without the express permission from Wiley. 
professional role socialization and illustrate differences in nurses' perceptions based on hospital setting. It contributes to the growing evidence around the influence of a nurse residency program in fostering effective transition to practice. The study took place in one Midwestern state in the United States; therefore, the findings may not be generalizable to other states and countries. Dissimilarities in sample size and response rate between the rural and urban residents are also limitations. Finally, it is unknown whether data were biased due to possible differences between non-respondents and participants.

\section{Implications for Nursing Management}

These results suggest that a well-designed nurse residency program has deeply embedded elements that keep nurses in their jobs, including maintenance of clinical skill competence, presence of a social support network, access to further training, and guidance from experienced nurses (Hegney et al. 2002). A residency program is a valuable organizational investment as part of a hospital's continuing education and staff development activities which ultimately increases organizational commitment and decreases nurse turnover (Dawley et al. 2010, Rondeau et al. 2009, Stone et al. 2007). Based on our results, management efforts to diminish work environment factors that cause stress - adequacy of supplies, access to resources, and staffing to enable nurses to deliver care - are worthwhile. Special attention is warranted for rural settings where nurses have fewer support services and tend to rely more heavily on managers for support. In fact, rural nurses highly value managers' assistance with physical work tasks (MacPhee \& Scott 2002). Since nurse staffing is associated with job satisfaction and turnover intent (Letvak \& Buck 2008, Wagner 2010), it is essential to ensure that there are appropriate personnel and other resources for nurses in both rural and urban areas.

In rural settings, fitting in, having a sense of belonging, and satisfaction with the community are extremely important to nurses' job satisfaction and intent to stay (Berkus \& MacLeod 2004, Hegney et al. 2002, Penz et al. 2008). Therefore, it is important that rural managers take steps to ensure appropriate socialization of new nurses, not only to the workplace, but also to the community. Upon hire, rural nurse managers may find it valuable to deploy strategies that foster the new

Journal of Nursing Management, Vol. 22, No. 6 (September 2014): pg. 779-791. DOI. This article is (C) Wiley and permission has been granted for this version to appear in e-Publications@Marquette. Wiley does not grant permission for this article to be further copied/distributed or hosted elsewhere without the express permission from Wiley. 
nurses' connection to the community, such as providing information on community events and encouraging involvement in these activities (Stroth 2010).

Furthermore, based on the differences between rural and urban nursing practice, a nurse residency program must take into consideration the unique attributes of nursing care delivery that are setting-driven. This will result in creation of a program that is specifically tailored to building new nurses' competent delivery of population-specific care within the context of their respective healthcare organizations and communities.

Lastly, since this study found that rural nurse residents had increased job satisfaction and decreased stress compared to urban residents, nurse residency programs can be powerful marketing tools to attract newly licensed nurses to the rural hospital setting. With the current state of the economy many recently graduated nurses are finding it increasingly challenging to find jobs in urban hospital settings. Rural hospital nursing is an extremely attractive alternative especially if new nurses are offered the professional development education and a social support network that a nurse residency program provides. Regardless of setting, a nurse residency program is a powerful recruitment tool and can serve to maintain a competent nurse workforce.

\section{Conclusions}

This study provides compelling evidence that rural and urban residents differed in their perceptions of their work environment during the residency program. Particularly at program end, rural residents had higher levels of job satisfaction and lower levels of stress compared to urban residents. The unique context of rural versus urban nursing practice - particularly nurses' relationship with their community, aspects of the work setting, patient acuity, professional autonomy, and role demands - may best account for the differences found. Furthermore, due to the professional isolation that new rural nurses experience, rural residents may have received more benefits from the social support aspect of the residency program, which could have contributed to promoting job stress resiliency. While future

Journal of Nursing Management, Vol. 22, No. 6 (September 2014): pg. 779-791. DOI. This article is @ Wiley and permission has been granted for this version to appear in e-Publications@Marquette. Wiley does not grant permission for this article to be further copied/distributed or hosted elsewhere without the express permission from Wiley. 
studies to examine possible impact of nurse residency programs on patient and organizational outcomes as well as cost effectiveness of these programs are needed, our results suggest that a nurse residency program is a viable mechanism to guard against factors that promote new graduate nurse turnover and therefore warrants dedication of financial and staff development resources.

\section{References}

Albion, J., Fogarty, G. \& Machin, M. (2005) Benchmarking occupational stressors and strain levels for rural nurses and other health sector workers. Journal of Nursing Management 13(5), 411-418.

Anderson, T. \& Linden, L. (2009) New graduate RN work satisfaction after completing an interactive nurse residency. The Journal of Nursing Administration 39 (4), 165-169.

Berkus, M.H. \& MacLeod, M.L. (2004) Retaining public health nurses in rural British Columbia: The influence of job and community satisfaction. Canadian Journal of Public Health 95(1), 54-58.

Baernholdt, M. \& Mark, B.A. (2009) The nurse work environment, job satisfaction and turnover rates in rural and urban nursing units. Journal of Nursing Management 17(8), 994-1001.

Baernholdt, M., Jennings, B.M., Merwin, E. \& Thornlow, D. (2010) What does quality care mean to nurses in rural hospitals? Journal of Advanced Nursing 66(6), 1346-1355.

Beatty, R.M. (2001) Continuing professional education, organization support and profession competence: Dilemmas of rural nurses. Journal of Continuing Education in Nursing 32(5), 203-209.

Beecroft, P.C., Dorey, F. \& Wenten, M. (2008) Turnover intention in new graduate nurses: a multivariate analysis. Journal of Advanced Nursing 62(1), 41-52.

Beecroft, P.C., Kunzman, L. \& Krozek, C. (2001) RN internship: Outcomes of a one-year pilot program. Journal of Nursing Administration 31(12), 575-582.

Benner, B., Tanner, C. \& Chesla, C. (2009) Expertise in Nursing Practice: Caring, Clinical Judgment and Ethics, $2^{\text {nd }}$ edn. Springer Publishing, New York, NY.

Beyea, S.C., von Reyn, L. \& Slattery, M.J. (2007) A nurse residency program for competency development using human patient

Journal of Nursing Management, Vol. 22, No. 6 (September 2014): pg. 779-791. DOI. This article is (C) Wiley and permission has been granted for this version to appear in e-Publications@Marquette. Wiley does not grant permission for this article to be further copied/distributed or hosted elsewhere without the express permission from Wiley. 
simulation. Journal for Nurses in Staff Development 23(2), 7782.

Bowles C. \& Candela L. (2005) First job experiences of recent RN graduates: Improving the work environment. Journal of Nursing Administration 35 (3), 130-137.

Bratt, M.M. (2009) Retaining the next generation of nurses: The Wisconsin nurse residency program provides a continuum of support. Journal of Continuing Education in Nursing 40(9) 416425.

Bratt, M.M. \& Felzer, H.M. (In press) Predictors of new graduate nurses' organizational commitment during a nurse residency program. Journal for Nurses in Staff Development.

Bratt, M.M. \& Felzer, H.M. (2011) Perceptions of professional practice and work environment of new graduates in a nurse residency program. Journal of Continuing Education in Nursing 42(12), 559-568.

Brewer, C.S., Kovner, C. T., Greene, W. \& Cheng, Y. (2009) Predictors of RNs' intent to work and work decisions 1 year later in a U.S. national sample. International Journal of Nursing Studies 46(7), 940-956.

Buerhaus, P.I., Auerbach, D.I. \& Staiger, D.O. (2009) The recent surge in nurse employment: Causes and implications. Health Affairs 28(4), 657-668.

Bushy, A. (2000) Orientation to Nursing in the Rural Community. Sage Publications Inc, Thousand Oaks, CA.

Bushy, A. (2002) International perspectives on rural nursing: Australia, Canada, USA. Australian Journal of Rural Health 10, 104-111.

Casey, K., Fink, R., Krugman, M. \& Propst, J. (2004) The graduate nurse experience. Journal of Nursing Administration 34(6), 303311.

Coomber, B. \& Barriball, K.L. (2007) Impact of job satisfaction components on intent to leave and turnover for hospital-based nurses: A review of the literature. International Journal of Nursing Studies 44, 297-314.

Dawley, D., Houghton, J.D. \& Bucklew, N.S. (2010) Perceived organizational support and turnover intention: The mediating effects of personal sacrifice and job fit. The Journal of Social Psychology 150(3), 238-257.

Journal of Nursing Management, Vol. 22, No. 6 (September 2014): pg. 779-791. DOI. This article is @ Wiley and permission has been granted for this version to appear in e-Publications@Marquette. Wiley does not grant permission for this article to be further copied/distributed or hosted elsewhere without the express permission from Wiley. 
Duchscher, J.B. (2008) A process of becoming: The stages of new nursing graduate professional role transition. Journal of Continuing Education in Nursing 39(10), 441-450.

Duchscher, J.B. \& Myrick, F. (2008). The prevailing winds of oppression: Understanding the new graduate experience in acute care. Nursing Forum 43(4), 191-206.

Dyess, S.M. \& Sherman, R.O. (2009) The first year of practice: New graduate nurses' transition and learning needs. Journal of Continuing Education in Nursing 40(9), 403-410.

Elfering, A., Semmer, N.K. \& Grebner, S. (2006) Work stress and patient safety: Observer-rated work stressors as predictors of characteristics of safety-related events reported by young nurses. Ergonomic 49(5-6), 457-469.

Fink, R., Krugman, M., Casey, K. \& Goode, C. (2008) The graduate nurse experience: Qualitative residency program outcomes. Journal of Nursing Administration 38(7/8), 341-348.

Goode, C., Lynn, M., Krsek, C. \& Bednash, G. (2009) Nurse residency programs: An essential requirement for nursing. Nursing Economic \$27(3), 142-159.

Griffin, M. (2004) Teaching cognitive rehearsal as a shield for lateral violence: An intervention for newly licensed nurses. Journal of Continuing Education in Nursing 34(6), 257-263.

Halfer, D. (2007) A magnetic strategy for new graduate nurses. Nursing Economic\$25(1), 6-11.

Hausser, A.H., Mojzisch, A., Miesel, M. \& Schultz-Hardt, S. (2010) Ten years on: A review of recent research on the job demandcontrol (support) model and psychological well-being. Work \& Stress 24(1), 1-35.

Hegney, D. \& McCarthy, A. (2000) Job satisfaction and nurses in rural Australia. Journal of Nursing Administration 30(7/8), 347-350.

Hegney, D., McCarthy, A., Rogers-Clark, C. \& Gorman, D. (2002) Retaining rural and remote area nurses: The Queensland, Australia experience. Journal of Nursing Administration, 32(3), 128-135.

Hinshaw, A. \& Atwood, J. (1983) Nursing staff turnover, stress, and satisfaction: Models, measures and management. Annual Review of Nursing Research 1, 133-153.

Journal of Nursing Management, Vol. 22, No. 6 (September 2014): pg. 779-791. DOI. This article is (C) Wiley and permission has been granted for this version to appear in e-Publications@Marquette. Wiley does not grant permission for this article to be further copied/distributed or hosted elsewhere without the express permission from Wiley. 
Hurme, E. (2009) Competencies for nursing practice in a rural critical access hospital. Online Journal of Rural Nursing and Health Care $9(2), 67-81$.

Ingersoll, G.L., Olsan, T., Drew-Cates, J., Devinney, B.C. \& Davies, J. (2002) Nurses' job satisfaction, organizational commitment, and career intent. Journal of Nursing Administration 32 (5), 250263.

IOM, Institute of Medicine (2005) Quality through Collaboration: The Future of Rural Health. National Academies Press, Washington, DC.

Janssen, P.M., De Jonge, J. \& Bakker, A.B. (1999) Specific determinants of intrinsic work motivation, burnout and turnover intentions: A study among nurses. Journal of Advanced Nursing 29(6), 1360-1369.

Jenkins, H.M. (1985) A research tool for measuring perceptions of clinical decision making. Journal of Professional Nursing 1(4), 221-229.

Jukkala, A.M., Henly, S.J. \& Lindeke, L.L. (2008) Rural perceptions of continuing professional education. Journal of Continuing Education in Nursing 39(12), 555-563.

Karasek R.A. (1979) Job demands, job decision latitude and mental strain: Implications for job redesign. Administrative Science Quarterly 24, 285-308.

Keahey, S. (2008) Against the odds: Orienting and retaining rural nurses. Journal for Nurses in Staff Development 24(2), E15-20.

Keller, J., Meekins, K. \& Summers, B. (2006) Pearls and pitfalls of a new graduate academic residency program. Journal of Nursing Administration 36(12), 589-598.

Kenny, A. \& Duckett, S. (2003) Educating for rural nursing practice. Journal of Advanced Nursing, 44(6), 613-622.

Krebs, J.P., Madigan, E.A. \& Tullai-McGuinness, S. (2008) The rural nurse work environment and structural empowerment. Policy, Politics, \& Nursing Practice 9(1), 28-39.

Kramer, M., Maguire, P., Halfer, D., Brewer, B. \& Schmalenberg, C. (2011) Impact of residency programs on professional socialization of newly licensed registered nurses. Western Journal of Nursing Research, available at http://wjn.sagepub.com/content/early/2011/07/31/0193945911 415555, doi10.1177/0193945911415555.

Journal of Nursing Management, Vol. 22, No. 6 (September 2014): pg. 779-791. DOI. This article is (C) Wiley and permission has been granted for this version to appear in e-Publications@Marquette. Wiley does not grant permission for this article to be further copied/distributed or hosted elsewhere without the express permission from Wiley. 
Krugman, M., Bretschneider, J., Horn, P.B., Krsek, C.A., Moutafus, R.A. \& Smith, M.O. (2006) The national post-baccalaureate graduate nurse residency program: A model for excellence in transition to practice. Journal for Nurses in Staff Development 22(4), 196-205.

LaSala, K.B. (2000) Nursing workforce issues in rural and urban settings: Looking at the differences in recruitment, retention, and distribution. Online Journal of Rural Nursing and Health Care 1, 8-17.

Laschinger, H., Almost, J. \& Tuer-Hodes, D. (2003) Workplace empowerment and magnet hospital characteristics: Making the link. Journal of Nursing Administration 33(7/8), 410-422.

Lea, J. \& Cruickshank, M. (2005) Factors that influence recruitment and retention of graduate nurses in rural health care facilities. Collegian 12(2), 22-27.

Lee, H.J. \& Winters, C.A. (eds) (2006). Rural Nursing: Concepts, Theory, and Practice. Springer Publishing, New York, NY.

Letvak, S. \& Buck, R. (2008) Factors influencing work productivity and intent to stay in nursing. Nursing Economic $\$ 26(3), 159-165$.

MacLeod, M.L., Lindsey, E., Ulrich, C., Fulton, T. \& John, N. (2008) The development of a practice-driven, reality-based program for rural acute care registered nurses. Journal of Continuing Education in Nursing 39(7), 298-304.

MacPhee, M. \& Scott, J. (2002) The role of social support networks for rural hospital nurses. Journal of Nursing Administration 32, 264272.

Marshalleck, E.F. (1997) The effect of education, job characteristics, and hospital unit structure on nurse performance and job satisfaction. Unpublished doctoral dissertation, Stanford University.

McCoy, C. (2009) Professional development in rural nursing: Challenges and opportunities. Journal of Continuing Education in Nursing 40(3), 128-31.

McKenna, B.G., Smith, N.A., Poole, S.J. \& Coverdale, J.H. (2003) Horizontal violence: experiences of registered nurses in their first year of practice. Journal of Advanced Nursing 42, 90-96. Mitchell, T.R., Holtom, B.C., Lee, T.W., Sablynski, T.W. \& Erez, M. (2001) Why people stay: Using job embeddedness to predict

Journal of Nursing Management, Vol. 22, No. 6 (September 2014): pg. 779-791. DOI. This article is (C Wiley and permission has been granted for this version to appear in e-Publications@Marquette. Wiley does not grant permission for this article to be further copied/distributed or hosted elsewhere without the express permission from Wiley. 
voluntary turnover. The Academy of Management Journal 44(6), 1102-1121.

Molinari, D., Monserud, M. \& Hudzinski, D. (2008) A new type of rural nurse residency. Journal of Continuing Education in Nursing, 39(1), 42-46.

Mowday, R.T., Steers, R.M. \& Porter, L.W. (1979) The measurement of organizational commitment. Journal of Vocational Behavior 14, 224-247.

Murray, M., Havener, J. \& Jastremski, C. (2011) The rural pipeline: Building a strong nursing workforce through academic and service partnerships. Nursing Clinics of North America 46(1), 107-121.

NCSBN, National Council of State Boards of Nursing (2009) Transition to practice:

Promoting public safety \& frequently asked questions. Available at: https://www.ncsbn.org, accessed on 10 December 2009.

Ndiwane, A. (2003) The effects of practice location and work setting on job satisfaction of nurses. Clinical Excellence for Nurse Practitioners 7(1-2), 27-33.

Pellico L.H., Brewer C.S. \& Kovner C.T. (2009) What newly licensed registered nurses have to say about their first experiences. Nursing Outlook 57, 194-203.

Penz, K., Stewart, N., D'Arcy, C. \& Morgan, D. (2008) Predictors of job satisfaction for rural acute care registered nurses in Canada. Western Journal of Nursing Research 30(7), 785-800.

Pine, R. \& Tart, K. (2007) Return on investment: Benefits and challenges of a baccalaureate nurse residency program. Nursing Economic\$25(1), 13-39.

Romyn, D.M., Linton, N., Giblin, C., Hendrickson, B., Houger Limacher, L., Murray, C., Nordstrom, P., Thauberger, G., Vosburgh, D., Vye-Rogers, L., Weidner, A. \& Zimmel, C. (2009) Successful transition of the new graduate nurse. International Journal of Nursing Education Scholarship 6(1)1-17.

Rondeau, K., Williams, E. \& Wagar, T. (2009) Developing human capital: What is the impact on nurse turnover? Journal of Nursing Management 17(6), 739-748.

Rosenfeld, P., Smith, M.O., Iervolino, L. \& Bowar-Ferres, S. (2004) Nurse resident program: A 5-year evaluation from the

Journal of Nursing Management, Vol. 22, No. 6 (September 2014): pg. 779-791. DOI. This article is (C Wiley and permission has been granted for this version to appear in e-Publications@Marquette. Wiley does not grant permission for this article to be further copied/distributed or hosted elsewhere without the express permission from Wiley. 
participant's perspective. Journal of Nursing Administration 34(4), 188-194.

Salt, J., Cummings, G. \& Profetto-McGrath, J. (2008) Increasing retention of new graduate nurses: A systematic review of interventions by healthcare organizations. Journal of Nursing Administration 38(6), 287-296.

Scharff, J.E. (2010) The distinctive nature and scope of rural nursing practice: Philosophical basis. In Rural Nursing: Concepts, Theory, and Practice $3^{\text {rd }}$ edn (Winters, C.A. \& Lee, H.J. eds), Springer Publishing Company, New York, NY, pp 249-268.

Schwirian, P.M. (1978) Evaluating the performance of nurses: A multidimensional approach. Nursing Research 27(6), 347-351.

Skillman, S.M., Palazzo, L., Hart, G.L. \& Butterfield, P. (2007) Changes in the Rural Registered Nurse Workforce from 1980 to 2004, (115). University of Washington, WWAMI Rural Health Research Center, Seattle, WA.

Squires, A. (2002) New graduate orientation in the rural community hospital. Journal of Continuing Education in Nursing 33(5), 203209.

Spector, N. \& Li, S. (2007) A regulatory model on transitioning nurses from education to practice. JONA's Healthcare Law, Ethics, and Regulation 9(1), 19-22.

Stone, P.W., Mooney-Kane, C., Larson, E.L., Pastor, D.K., Zwanzinger, J. \& Dick. A.W. (2007) Nursing work conditions, organizational climate, and intent to leave in ICUs: An instrumental variable approach. HSR Health Services Research 42(3), 1085-1104.

Stroth, C. (2010) Job embeddedness as a nurse retention strategy for rural hospitals. Journal of Nursing Administration 40(1), 32-35.

Ulrich, B., Krosek, C., Early, S., Ashlock. C., Africa, L. \& Carman, M. (2010) Improving retention and competence of new graduate nurses: Results from a 10-year longitudinal database. Nursing Economic\$, 28(6), 363-375.

Unruh, L.Y. \& Nooney, J. (2011) Newly licensed registered nurses' perceptions of job difficulties, demands and control: Individual and organizational predictors. Journal of Nursing Management $19,572-584$.

Wagner, C.M. (2007) Organizational commitment as a predictor variable in nursing turnover research: Literature review. Journal of Advanced Nursing 60(3), 235-247.

Journal of Nursing Management, Vol. 22, No. 6 (September 2014): pg. 779-791. DOI. This article is (C Wiley and permission has been granted for this version to appear in e-Publications@Marquette. Wiley does not grant permission for this article to be further copied/distributed or hosted elsewhere without the express permission from Wiley. 
NOT THE PUBLISHED VERSION; this is the author's final, peer-reviewed manuscript. The published version may be accessed by following the link in the citation at the bottom of the page.

Williams, C., Goode, C. \& Krsek, C. (2007) Post baccalaureate nurse residency 1-year outcomes. The Journal of Nursing Administration 37(7/8), 357-365.

Winters, C.A. \& Mayer, D.M. (2002). Special feature: An approach to cardiac care in rural settings. Critical Care Nursing Quarterly 24(4), 75-82.

Zibrik, K.J., MacLeod, M.L., \& Zimmer, L.V. (2010) Professionalism in rural acute-care nursing. Canadian Journal of Nursing Research $42(1), 20-36$. 
NOT THE PUBLISHED VERSION; this is the author's final, peer-reviewed manuscript. The published version may be accessed by following the link in the citation at the bottom of the page.

\section{Table 1: Rural and Urban Nurse Resident Demographic, Prelicensure Education and Post-hire Job Characteristics}

\begin{tabular}{|c|c|c|}
\hline & $\begin{array}{l}\text { Rural Sample } \\
\qquad \mathrm{N}=86(18.4 \%)\end{array}$ & $\begin{array}{l}\text { Urban Sample } \\
\mathrm{N}=382(81.6 \%)\end{array}$ \\
\hline $\begin{array}{l}\text { Demographic and Prelicensure } \\
\text { Education Characteristics }\end{array}$ & $M(S D) / \%$ & $M(S D) / \%$ \\
\hline Age ** & $33.4(9.2)$ & $29.2(7.9)$ \\
\hline $\begin{array}{l}\text { Gender } \\
\text { Female } \\
\text { Male }\end{array}$ & $\begin{array}{r}98.8 \% \\
1.2 \%\end{array}$ & $\begin{array}{r}93.2 \% \\
6.8 \%\end{array}$ \\
\hline $\begin{array}{l}\text { Race * } \\
\text { White } \\
\begin{array}{l}\text { Non-white } \\
\text { Asian } \\
\text { Black } \\
\text { Hispanic/Latino } \\
\text { More than one race }\end{array}\end{array}$ & $100 \%$ & $\begin{array}{r}89.6 \% \\
\\
.8 \% \\
4.3 \% \\
2.3 \% \\
3 \% \\
\end{array}$ \\
\hline $\begin{array}{c}\text { Degree } * * \\
\text { ADN } \\
\text { BSN } \\
\end{array}$ & $\begin{array}{l}87.1 \% \\
12.9 \% \\
\end{array}$ & $\begin{array}{l}48.1 \% \\
51.9 \%\end{array}$ \\
\hline $\begin{array}{l}\text { Prior Non-nursing Degree } \\
\text { Yes } \\
\text { No }\end{array}$ & $\begin{array}{l}24.7 \% \\
75.3 \% \\
\end{array}$ & $\begin{array}{l}23.5 \% \\
76.5 \%\end{array}$ \\
\hline $\begin{array}{l}\text { Prelicensure Socialization Course } \\
\text { Yes } \\
\text { No }\end{array}$ & $\begin{array}{l}70.4 \% \\
29.6 \%\end{array}$ & $\begin{array}{r}64.0 \% \\
36 \%\end{array}$ \\
\hline Hours with Preceptor Prelicensure $* *$ & $67.7(51.4)$ & $119.7(118.8)$ \\
\hline Post-Hire Job Characteristics & & \\
\hline $\begin{array}{l}\text { In Desired Position } \\
\text { Yes } \\
\text { No }\end{array}$ & $\begin{array}{l}86.3 \% \\
13.7 \%\end{array}$ & $\begin{array}{l}76.7 \% \\
23.3 \%\end{array}$ \\
\hline $\begin{array}{l}\text { Orientation Objectives Met } \\
\text { Yes } \\
\text { No }\end{array}$ & $\begin{array}{r}92.4 \% \\
7.6 \%\end{array}$ & $\begin{array}{l}88.1 \% \\
11.9 \%\end{array}$ \\
\hline Hours/week worked & $34.3(5.7)$ & $35.6(7.0)$ \\
\hline Length of Classroom Orientation (hours) & $39.7(43.8)$ & $53.0(73.5)$ \\
\hline Length of Precepted Experience (weeks) & $9.7(7.1)$ & $9.5(5.0)$ \\
\hline Number of Preceptors $* *$ & $3.8(2.3)$ & $4.9(3.1)$ \\
\hline
\end{tabular}

Significant Differences between Samples

$* \mathrm{p}<.01 ; * * \mathrm{p}<.001$ 
NOT THE PUBLISHED VERSION; this is the author's final, peer-reviewed manuscript. The published version may be accessed by following the link in the citation at the bottom of the page.

Table 2: Program Outcomes: Time by Group Means and Standard Error

\begin{tabular}{|c|c|c|c|c|c|c|}
\hline \multirow{2}{*}{$\begin{array}{l}\text { Program } \\
\text { Outcomes } \\
\text { Total Scale } \\
\text { Subscales }\end{array}$} & \multicolumn{2}{|c|}{$\begin{array}{l}\text { Time } 1 \text { (Baseline) } \\
\text { Mean } \pm S E\end{array}$} & \multicolumn{2}{|c|}{$\begin{array}{l}\text { Time } 2 \text { (6 Months) } \\
\text { Mean } \pm S E\end{array}$} & \multicolumn{2}{|c|}{$\begin{array}{l}\text { Time } 3 \text { (12 Months) } \\
\text { Mean } \pm \text { SE }\end{array}$} \\
\hline & Rural & Urban & Rural & Urban & Rural & Urban \\
\hline $\begin{array}{l}\text { Decision } \\
\text { Making }\end{array}$ & $\begin{array}{l}144.0 \pm \\
1.57\end{array}$ & $\begin{array}{l}143.5 \pm \\
0.65\end{array}$ & $\begin{array}{l}143.3 \pm \\
1.64\end{array}$ & $\begin{array}{l}142.1 \pm \\
0.68\end{array}$ & $\begin{array}{l}145.6 \pm \\
1.73\end{array}$ & $\begin{array}{l}143.9 \pm \\
0.72 \\
B^{*}\end{array}$ \\
\hline $\begin{array}{l}\text { Job } \\
\text { Satisfaction }\end{array}$ & $\begin{array}{l}82.6 \pm \\
1.24\end{array}$ & $\begin{array}{l}79.7 \pm \\
0.61\end{array}$ & $\begin{array}{l}82.3 \pm \\
1.33\end{array}$ & $\begin{array}{l}78.4 \pm \\
0.64\end{array}$ & $\begin{array}{l}85.7 \pm \\
1.34\end{array}$ & $\begin{array}{l}81.2 \pm \\
0.65 \\
\mathrm{~B}^{* * * *}\end{array}$ \\
\hline Enjoyment & $\begin{array}{l}42.6 \pm \\
0.67\end{array}$ & $\begin{array}{l}41.3 \pm \\
0.35\end{array}$ & $\begin{array}{l}41.8 \pm \\
0.71\end{array}$ & $\begin{array}{l}40.2 \pm \\
0.34 \\
A^{*}\end{array}$ & $\begin{array}{l}42.8 \pm \\
0.72\end{array}$ & $\begin{array}{l}41.0 \pm \\
0.35\end{array}$ \\
\hline Quality of Care & $\begin{array}{l}25.7 \pm \\
0.4\end{array}$ & $\begin{array}{l}24.6 \pm \\
0.22\end{array}$ & $\begin{array}{l}26.0 \pm \\
0.5\end{array}$ & $\begin{array}{l}24.5 \pm \\
0.24\end{array}$ & $\begin{array}{l}27.2 \pm \\
0.5 \\
A^{*}\end{array}$ & $\begin{array}{l}25.6 \pm \\
0.24 \\
A * * \\
B * * *\end{array}$ \\
\hline Time for Care & $\begin{array}{l}14.3 \pm \\
0.41\end{array}$ & $\begin{array}{l}13.7 \pm \\
0.20\end{array}$ & $\begin{array}{l}14.5 \pm \\
0.44\end{array}$ & $\begin{array}{l}13.7 \pm \\
0.21\end{array}$ & $\begin{array}{l}15.7 \pm \\
0.44 \\
A^{*}\end{array}$ & $\begin{array}{l}14.5 \pm \\
0.22 \\
A * * \\
B * *\end{array}$ \\
\hline Job Stress & $\begin{array}{l}47.6 \pm \\
0.98\end{array}$ & $\begin{array}{l}49.5 \pm \\
0.48\end{array}$ & $\begin{array}{l}47.2 \pm \\
1.05\end{array}$ & $\begin{array}{l}49.9 \pm \\
0.50\end{array}$ & $\begin{array}{l}43.0 \pm \\
1.06 \\
A^{* * *} \\
B * *\end{array}$ & $\begin{array}{l}47.6 \pm \\
0.52 \\
A * * \\
B * * *\end{array}$ \\
\hline Competence & $\begin{array}{l}14.6 \pm \\
0.32\end{array}$ & $\begin{array}{l}14.7 \pm \\
0.16\end{array}$ & $\begin{array}{l}13.6 \pm \\
0.35 \\
A^{*}\end{array}$ & $\begin{array}{l}14.0 \pm \\
0.17 \\
A^{* * *}\end{array}$ & $\begin{array}{l}11.7 \pm \\
0.35 \\
\mathrm{~A}^{* * *} \\
\mathrm{~B} * * *\end{array}$ & $\begin{array}{l}12.6 \pm \\
0.17 \\
\mathrm{~A} * * * \\
\mathrm{~B} * * *\end{array}$ \\
\hline $\begin{array}{l}\text { Physical } \\
\text { Environment }\end{array}$ & $\begin{array}{l}9.0 \pm \\
0.28\end{array}$ & $\begin{array}{l}10.2 \pm \\
0.14\end{array}$ & $\begin{array}{l}9.3 \pm \\
0.31\end{array}$ & $\begin{array}{l}10.6 \pm \\
0.15\end{array}$ & $\begin{array}{l}9.5 \pm \\
0.31\end{array}$ & $\begin{array}{l}10.6 \pm \\
0.15\end{array}$ \\
\hline Staffing & $\begin{array}{l}13.8 \pm \\
0.38\end{array}$ & $\begin{array}{l}14.4 \pm \\
0.19\end{array}$ & $\begin{array}{l}14.4 \pm \\
0.4\end{array}$ & $\begin{array}{l}15.2 \pm \\
0.20 \\
A^{* * *}\end{array}$ & $\begin{array}{l}12.9 \pm \\
0.4 \\
B^{*}\end{array}$ & $\begin{array}{l}14.8 \pm \\
0.21\end{array}$ \\
\hline Team Respect & $\begin{array}{l}10.2 \pm \\
0.30\end{array}$ & $\begin{array}{l}10.2 \pm \\
0.15\end{array}$ & $\begin{array}{l}9.8 \pm \\
0.32\end{array}$ & $\begin{array}{l}10.1 \pm \\
0.16\end{array}$ & $\begin{array}{l}8.9 \pm \\
0.33 \\
A^{* *}\end{array}$ & $\begin{array}{l}9.6 \pm \\
0.16 \\
A^{* * *} \\
B^{* * *}\end{array}$ \\
\hline $\begin{array}{l}\text { Nursing } \\
\text { Performance }\end{array}$ & $\begin{array}{l}166.4 \pm \\
2.80\end{array}$ & $\begin{array}{l}168.5 \pm \\
1.38\end{array}$ & $\begin{array}{l}180.3 \pm \\
3.02 \\
A^{* * *}\end{array}$ & $\begin{array}{l}178.4 \pm \\
1.46 \\
A^{* * *}\end{array}$ & $\begin{array}{l}195.5 \pm \\
3.06 \\
\mathrm{~A}^{* * *} \\
\mathrm{~B} * * *\end{array}$ & $\begin{array}{l}194.6 \pm \\
1.50 \\
\mathrm{~A}^{* * * *} \\
\mathrm{~B}^{* * *}\end{array}$ \\
\hline $\begin{array}{l}\text { Organizational } \\
\text { Commitment }\end{array}$ & $\begin{array}{l}76.1 \pm \\
1.52\end{array}$ & $\begin{array}{l}78.5 \pm \\
0.74\end{array}$ & $\begin{array}{l}74.1 \pm \\
1.62\end{array}$ & $\begin{array}{l}74.6 \pm \\
0.78 \\
A^{* * *}\end{array}$ & $\begin{array}{l}75.4 \pm \\
1.65\end{array}$ & $\begin{array}{l}74.8 \pm \\
0.80 \\
A^{* * *}\end{array}$ \\
\hline
\end{tabular}

Outlined cells indicate significant differences between rural and urban residents at specific time

A - Within-in Group Significant Differences from Time 1 (Baseline)

B - Within-in Group Significant Differences between Time 2 and Time 3

$* \mathrm{p}<.05 ; * * \mathrm{p}<.01, * * * \mathrm{p}<.001$

Journal of Nursing Management, Vol. 22, No. 6 (September 2014): pg. 779-791. DOI. This article is (C Wiley and permission has been granted for this version to appear in e-Publications@Marquette. Wiley does not grant permission for this article to be further copied/distributed or hosted elsewhere without the express permission from Wiley. 
NOT THE PUBLISHED VERSION; this is the author's final, peer-reviewed manuscript. The published version may be accessed by following the link in the citation at the bottom of the page.

Figure 1. Between Groups Difference: Job Satisfaction



*Significant difference between rural and urban residents at program endpoint $\mathrm{p}<.05$

\section{Figure 2. Between Groups Difference: Job Stress}

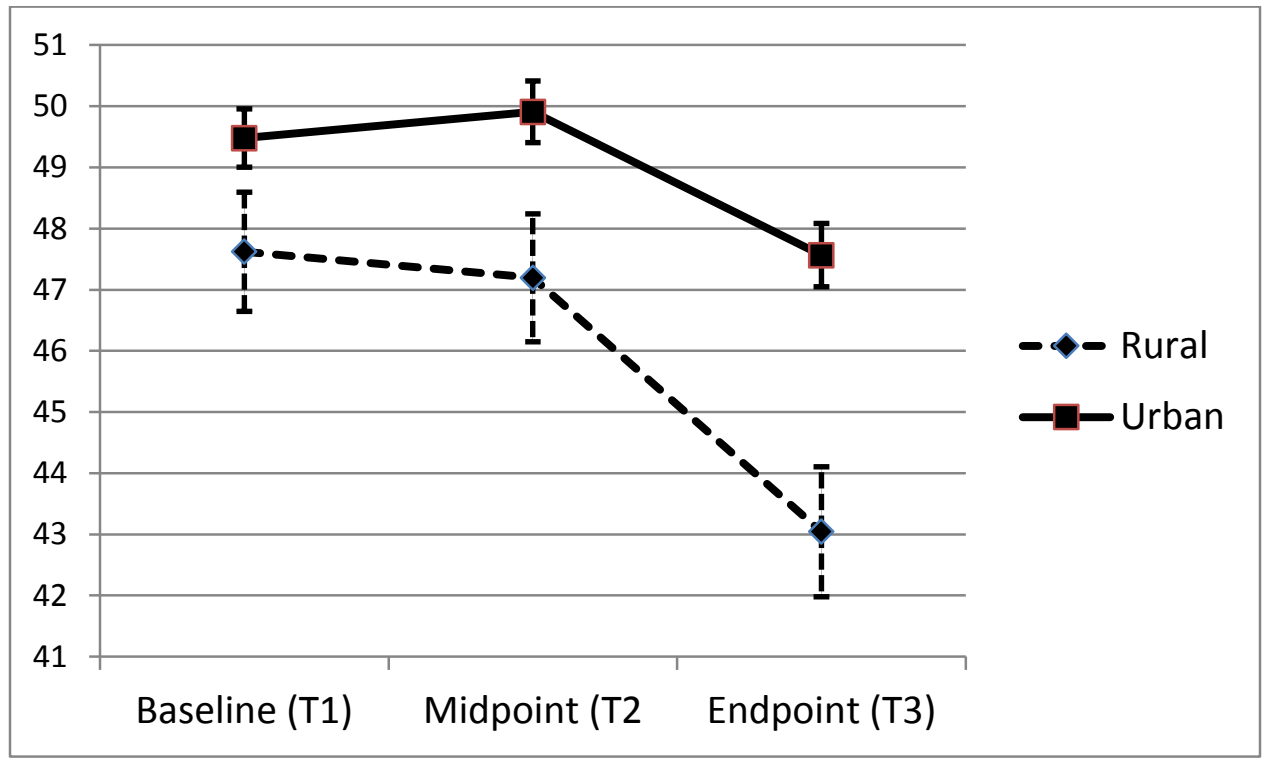

*Significant difference between rural and urban residents at program endpoint $\mathrm{p}<.01$ 
NOT THE PUBLISHED VERSION; this is the author's final, peer-reviewed manuscript. The published version may be accessed by following the link in the citation at the bottom of the page.

Figure 3. Between Groups Difference: Job Stress Physical Work Environment Subscale

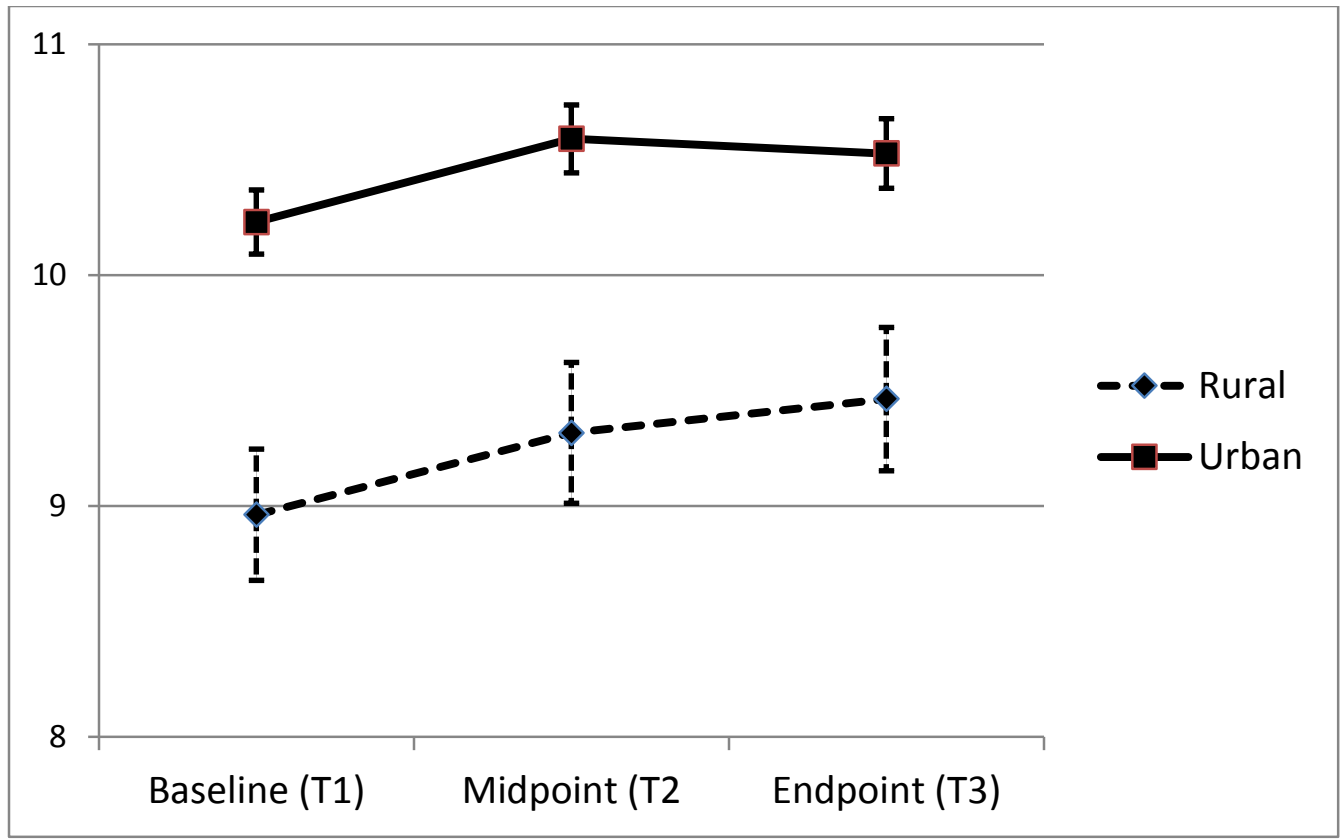

Significant difference between rural and urban residents at all times T1 $\mathrm{p}<.001 ; \mathrm{T} 2 \mathrm{p}<.01 ; \mathrm{T} 3 \mathrm{p}<.05$

Figure 4. Interaction between Setting and Time: Job Stress Staffing Subscale

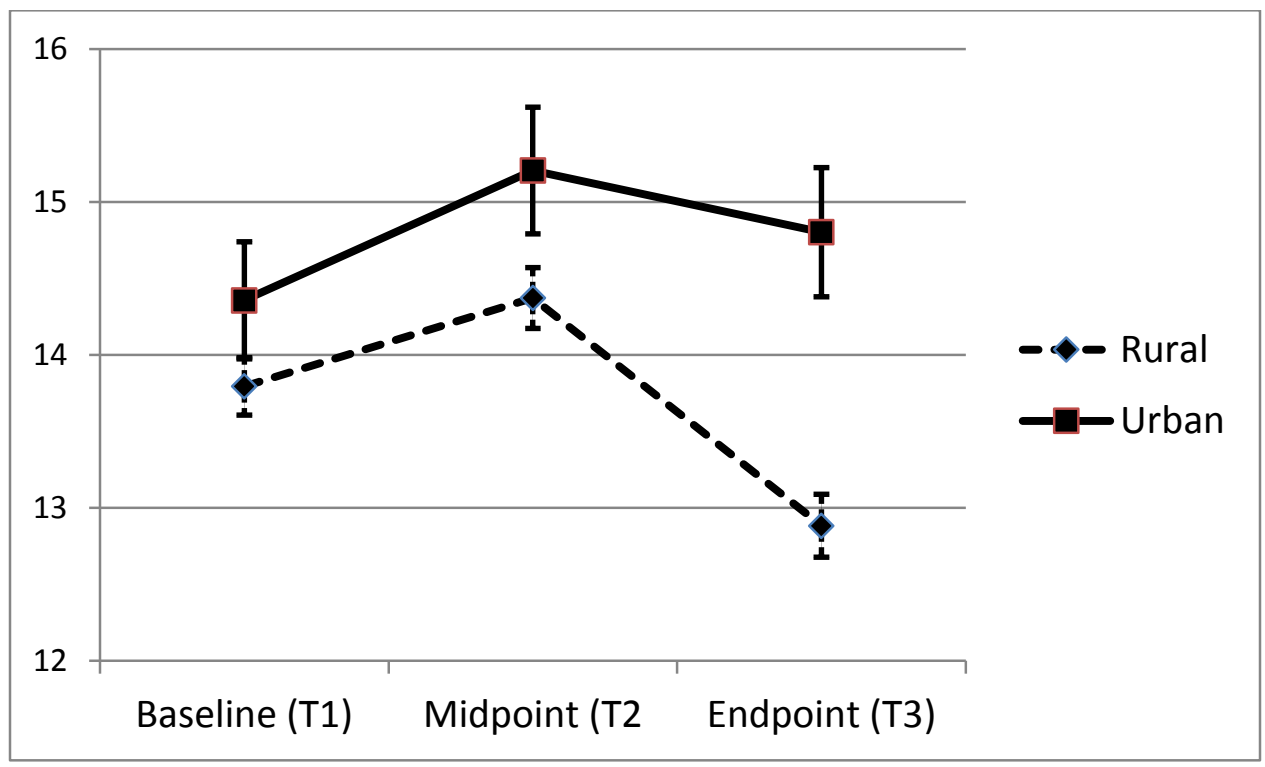

*Significant interaction between rural and urban settings over time $p<.05$

Journal of Nursing Management, Vol. 22, No. 6 (September 2014): pg. 779-791. DOI. This article is @ Wiley and permission has been granted for this version to appear in e-Publications@Marquette. Wiley does not grant permission for this article to be further copied/distributed or hosted elsewhere without the express permission from Wiley. 